\title{
Ways to improve the reproduction of fertility of southern chernozems
}

\author{
Olga Tomashova ${ }^{1, *}$, Nicolay Osenniy ${ }^{1}$, Aleksandr Ilyin ${ }^{1}$, and Lubov Veselova ${ }^{1}$ \\ ${ }^{1}$ V.I. Vernadsky Crimean Federal University, 295492, prosp. Vernadskogo, 4, Simferopol, Russia
}

\begin{abstract}
The analysis of the main historical stages of the development of the theory of minimization of tillage, as well as data obtained during longterm stationary studies, is made. Over the long-term period, the use of nondump resource-saving tillage in crop rotation was not inferior in efficiency, and in some indicators even exceeded the combined multi-depth tillage (including dump loosening of the soil). The data on the positive effect of the combination of the no-till system and the cultivation of groundcover crops in the crop rotation on the soil fertility with signs of its extended reproduction are presented.
\end{abstract}

\section{Introduction}

Modern agricultural systems rely heavily on intensive tillage and inorganic fertilizers. This tradition increases the cost of agricultural production and negatively affects agricultural systems and the environment. Conservation methods such as cover crops (CCs) and no-till (NT) can serve as a management approach to promote soil health and agricultural sustainability [1].

The introduction of efficient and sustainable agriculture requires a deeper understanding of the impact of conservation tillage methods on the physical properties of the soil. The results of the studies showed that non-fall tillage (NT), residual tillage (NT), and reduced tillage (RT) increase the bulk density by $1.4,2.6$, and $2.1 \%$, respectively, compared to conventional tillage (CT) [2].

The use of conservation tillage methods, such as zero tillage, can improve the quality of the soil compared to conventional tillage methods that disrupt the soil structure. The advantages of preserving the soil structure without tillage usually lead to an improvement in biological processes and an increase in the biological diversity of microorganisms [3].

In a number of experiments, organic farming combined with reduced tillage improved the soil structure [4]. The depth of tillage is a significant factor that reflects the contact area of the soil with the tillage tool [5].

Studies by individual authors have shown that the strategic use of tillage within the notill system otherwise leads to a minor and short-term impact on soil conditions $[6,7]$.

The intensity of tillage can greatly affect the biological indicators of soil health. Reducing the intensity of tillage improves the SOC, biological activity, and labile C-and Nfractions of COM $[8,9]$.

\footnotetext{
* Corresponding author: 777tom@bk.ru
} 
Reduced tillage results in higher (1967-1976) or similar (1977-2016) wheat yields than with a conventional plow. Reduced tillage maintains a 7\% higher organic carbon content (SOC) in the soil than a conventional plow [10]. Non-tillage of the soil did not affect the annual NO emissions in the crop rotation system of corn and wheat [11].

Reducing tillage has both advantages and disadvantages. Cover farming could help mitigate these negative effects. Field experience shows the importance of cover crops in no systems yet. The highest yield of wheat is achieved with minimal soil treatment with field peas as a cover crop. The combination of cover crops and reduced tillage increases soil fertility [12-13].

The 23-year-old NT system resulted in higher soil fertility in the topsoil compared to CT. HT creates a strong gradient of nutrient availability, which decreases sharply with depth. The cultivation of cover crops in winter is effective for increasing the availability of $\mathrm{P}$ and $\mathrm{K}[14]$.

Plant residue retention and minimal tillage (including no tillage, NT and repeated tillage, RT) are common conservation tillage methods that are widely used to improve soil health and reduce the negative environmental impact caused by intensive farming [15].

The periods of development of agriculture, covering the 18-21 century of the New Era, are only a moment in the history of mankind, but they had a revolutionary impact on the ordering of scientific views on the development of tillage systems, and the depth of their influence on the formation of soil fertility, negative processes of destructive nature threaten not only the level of food supply of the population of most countries of the world, but also the very life of the inhabitants of the modern world and Man above all.

Up to the beginning of the XX century, in the conditions of the superiority of extensive and progressive farming systems, the expansion of cultivated land was carried out with the use of plow processing, which ensures the turnover of the reservoir with the incorporation of plant residues, organic fertilizers and chemical meliorants into the soil. Plowing was also the main method of destroying the sod of newly developed lands, including virgin and fallow lands of Western Siberia and Northern Kazakhstan, as well as an agrotechnical means of combating perennial weeds.

At the same time, in the sixties of the 20th century, the processes of wind and water erosion were intensively manifested on the lands cultivated annually by the plow.

And although the replacement of the plow with tools of non-tillage reduced the processes of soil degradation, the alternation of deep, conventional and small-scale treatments required significant expenditures, including on fuel and lubricants. Only in the seventies and eighties, tillage occupied $40 \%$ of energy resources and $25 \%$ of labor costs in crop production technology (P. U. Bakhtin, 1969).

In the conditions of negative manifestation of dehumidification processes due to intensive mechanical tillage, directions for minimizing tillage were also formed in our country and abroad. In 1899, I. E. Ovsinsky in Bessarabia proposed a new system of tillage with the replacement of plowing by surface treatment with a cultivator or disc tools developed by him.

American farmer Edward H. Faulkner, in his book " Plowman's Folly " (1943), justified the inexpediency of plowing and other deep treatments and replacing them with surface loosening to seal the seeds of cultivated agricultural crops to the optimal depth.

The well-known scientist-agronomist T. S. Maltsev (1951) developed and implemented a system of non-tillage for the conditions of the Trans-Urals, which provides for deep loosening by $35-40 \mathrm{~cm}$ with a non-tillage plow once for $4-5$ years, and in the period between deep workings-annual shallow and surface work with disc huskers for $8-12 \mathrm{~cm}$.

Further study of tillage in the areas of wind erosion Russia was done by scientists at the national research Institute of grain farming (NRIGF) under the guidance of academician Barayev A. I. (1966). To protect the soil from blowing was proposed subsurface treatment 
system with preservation of the stubble on the surface reduce the wind speed in the surface layer and prevent deflation. The basis of the processing system was made up of tools for basic flat-cutting processing (KPG-250, KPG-2-150, GUN-4, etc.) and tools for small main and pre-sowing processing of vapors with the preservation of stubble (KPP-2.2, KPE-3.8, KTS-10-1, KWR-3.6, etc.), as well as stubble seeders SZS-2.1 and their analogues.

All the listed directions of searching for ways to minimize tillage could not be transferred for the arid conditions of the Crimea with an intense manifestation of wind and water erosion, and therefore it was necessary to study these issues in relation to local conditions.

For the first time in the conditions of stationary experiment in the arid conditions of the Crimea, Professor Gordienko V. P. (1980) established the possibility of minimizing the main and pre-sowing treatment of southern chernozems for field crops, performed fundamental research in the field of soil agrophysics, created mathematical models of mobility, availability and evaporation of soil moisture, changes in water-physical properties from their density. The results of these studies were included in the scientific and educational publications and is an important theoretical background to the practical matters of minimizing processing topsoil, widely recognized in many countries of the world. Requests for prints of these works were received from Argentina, the United States, (University of California, University of Kansas, University of Kentucky, Institute of Computer Science), Canada, Spain, France, and Czechoslovakia. Three articles have been translated into English.

It was on the basis of these studies that long-term field experiments were continued, which allowed us to deepen the study of generally accepted tillage systems and to take a very important step towards further substantiating the ways to minimize tillage, the rationale for which is set out in this article below.

\section{Materials and methods}

In a stationary field experiment for 19 years, the influence of tillage systems in combination with fertilizers in a field crop rotation on the reproduction of southern chernozem fertility and the yield of cultivated crops, including in two rotations in direct action and aftereffect, was studied (Osenniy N.G., Ilyin A.V., Veselova L.S.).

The studies were conducted in a long-term (1992-2013) stationary three - factor $(2 \times 3 \times 4)$ field experiment (Table 1) of the Department of Agriculture of the Crimean State Agrarian University with the following alternation of crop rotation crops: 1-pairs of annual sweet clover for green feed (1 rotation) and sainfoins for green feed (second rotation), 2 - winter wheat, 3 - winter barley, 4 - sunflower (in the second rotation - oilseed flax), 5 - sorghum for silage (MVS), 6 - winter wheat, 7-spring barley with seeding of sainfoin.

The soil of the experimental site is ordinary chernozem (according to the classification of Polovitsky I. Ya., Gusev P. G. (1987) - southern chernozem) with a humus content in the arable layer of $2.0-3.5 \%$, medium and high availability of mobile forms of phosphorus and exchangeable potassium. In the years of research, the amount of sediment ranged from 375 $\mathrm{mm}$ (2009) to $631.1 \mathrm{~mm}$ (2004), with an average annual amount of $509 \mathrm{~mm}$.

\section{Results and discussion}

It was found that the long-term (14 years) use of combined multi-depth processing in the field crop rotation with plowing at $18-20 \mathrm{~cm}$ for winter wheat after melilot (first rotation) and sainfoin for green fodder (second rotation) and at $25-27 \mathrm{~cm}$ for sorghum of milk - wax ripeness and non-dump resource-saving processing at the same depth (for the first winter wheat after melilot and sainfoin-fine processing with disk tools at $8-10 \mathrm{~cm}$ ) had a similar effect the main agrophysical, biological and agrochemical indicators of soil fertility. At the 
same time, the soil density of the arable layer was within the optimal value for grain crops and row crops $\left(1.08-1.29 \mathrm{~g} / \mathrm{cm}^{3}\right)$, while the equilibrium density of southern chernozem was $1.16-1.29 \mathrm{~g} / \mathrm{cm}^{3}$.

Table 2. The scheme of field experience.

\begin{tabular}{|c|c|c|c|c|c|c|c|c|}
\hline \multirow[b]{2}{*}{ 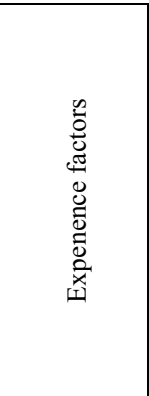 } & \multirow[b]{2}{*}{ 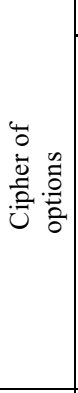 } & \multicolumn{7}{|c|}{ Crop rotation crops, the content of options } \\
\hline & & 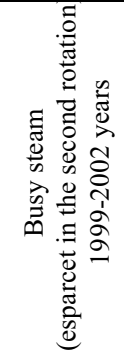 & 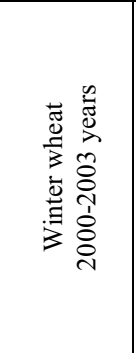 & 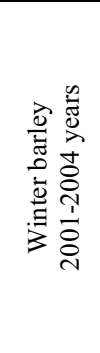 & 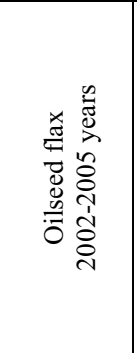 & 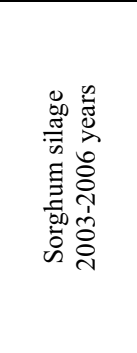 & 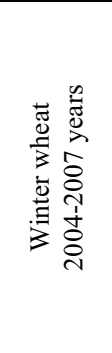 & 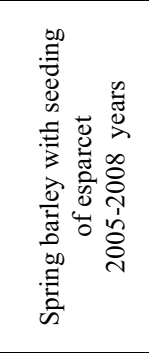 \\
\hline \multirow{4}{*}{ 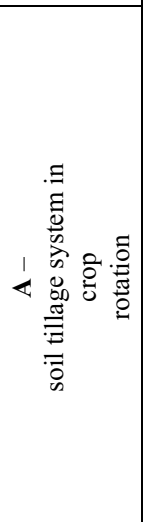 } & \multirow[b]{2}{*}{$A_{1}$} & \multicolumn{7}{|c|}{ Multi-depth combined } \\
\hline & & & 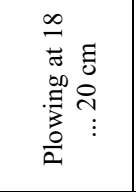 & 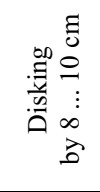 & 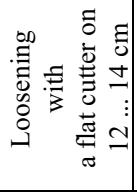 & 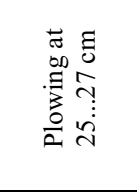 & 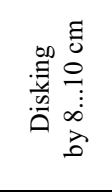 & 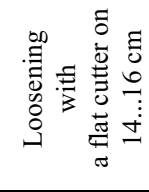 \\
\hline & & \multicolumn{7}{|c|}{ Resource-saving soil protection } \\
\hline & $\mathrm{A}_{2}$ & & 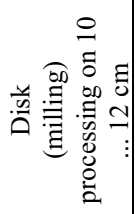 & 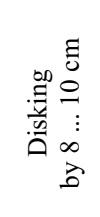 & 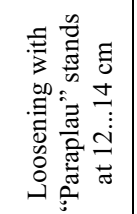 & 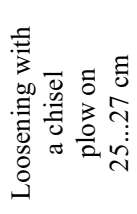 & 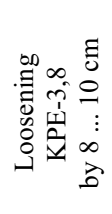 & 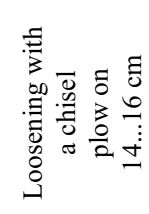 \\
\hline \multirow{3}{*}{ 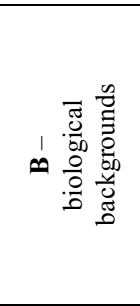 } & $\mathrm{B}_{1}$ & \multicolumn{7}{|c|}{$\begin{array}{c}\text { Generally accepted technology (without cultivation of green fertilizer, complete } \\
\text { removal of straw from the field) } \\
\text { Tillage following the harvesting of the predecessor }\end{array}$} \\
\hline & \multicolumn{8}{|c|}{ Common technology + sowing of intermediate crops on green fertilizer } \\
\hline & $\mathrm{B}_{1}$ & -”- & -”- & -”- & $\begin{array}{c}\text { sowing of } \\
\text { spring* } \\
\text { cabbage } \\
\text { for green } \\
\text { fertilizer }\end{array}$ & -”- & -”- & $\begin{array}{l}\text { sowing of } \\
\text { spring* } \\
\text { cabbage for } \\
\text { green } \\
\text { fertilizer }\end{array}$ \\
\hline \multirow{6}{*}{ 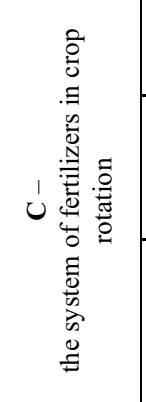 } & \multirow{2}{*}{$\mathrm{C}_{1}$} & \multicolumn{7}{|c|}{ Without fertilizers and pesticides (insectofungicides are used only for seed treatment) } \\
\hline & & & $\mathrm{H}_{0} \mathrm{~N}_{0} \mathrm{P}_{0}$ & $\mathrm{~N}_{0} \mathrm{P}_{0}$ & $\mathrm{~N}_{0} \mathrm{P}_{0}$ & $\mathrm{~N}_{0} \mathrm{P}_{0}$ & $\mathrm{~N}_{0} \mathrm{P}_{0}$ & $\mathrm{~N}_{0} \mathrm{P}_{0}$ \\
\hline & \multirow{2}{*}{$\mathrm{C}_{2}$} & \multicolumn{7}{|c|}{$\begin{array}{l}\text { Mineral fertilizer system } \\
\text { (based on the planned crop with the use of insectofungicides for seed treatment) }\end{array}$} \\
\hline & & & $\mathrm{H}_{0} \mathrm{~N}_{85} \mathrm{P}_{45}$ & $\mathrm{~N}_{110} \mathrm{P}_{35}$ & $\mathrm{~N}_{40} \mathrm{P}_{30}$ & $\mathrm{H}_{0} \mathrm{~N}_{90} \mathrm{P}_{35}$ & $\mathrm{~N}_{100} \mathrm{P}_{40}$ & $\begin{array}{c}\mathrm{N}_{70} \mathrm{P}_{35}+\mathrm{N} \\
{ }_{30} \mathrm{P}_{35} \\
\end{array}$ \\
\hline & \multirow[t]{2}{*}{$\mathrm{C}_{3}$} & \multicolumn{7}{|c|}{$\begin{array}{c}\text { Organic-mineral fertilizer system (manure of } 10 \mathrm{t} / \mathrm{ha}+\text { mineral fertilizers based on } \\
\text { the planned crop and the deficit-free balance of humus in the soil) with the use of } \\
\text { insectofungicides for seed treatment }\end{array}$} \\
\hline & & & $\begin{array}{c}\mathrm{H}_{30}{ }_{30 / \mathrm{ra}} \mathrm{N} \\
{ }_{60} \mathrm{P}_{10}\end{array}$ & $\mathrm{~N}_{75} \mathrm{P}_{30}$ & $\mathrm{~N}_{30} \mathrm{P}_{25}$ & $\begin{array}{c}\mathrm{H}_{40}{ }_{4} \mathrm{~T} / \mathrm{r} \mathrm{N} \\
{ }_{60} \mathrm{P}_{0}\end{array}$ & $\mathrm{~N}_{50} \mathrm{P}_{35}$ & $\begin{array}{c}\mathrm{N}_{55} \mathrm{P}_{30}+\mathrm{N} \\
{ }_{30} \mathrm{P}_{35} \\
\end{array}$ \\
\hline
\end{tabular}


The long-term use of a non-fallow resource-saving tillage system in crop rotation generally increased the anti-erosion stability of agricultural zones in comparison with a multi-depth combined soil protection system.

The long-term non-fallow resource-saving tillage system did not significantly increase the content of weed seeds in the arable layer $(0-30 \mathrm{~cm})$, however, in comparison with the mixed-depth combined system, it increased their number in the surface layer. So, if with a multi-depth combined treatment system, 30.8\% of weed seeds from $0-30 \mathrm{~cm}$ of the layer were concentrated in a layer of $0-10 \mathrm{~cm}$, then with a non-dump resource-saving one, it increased to $43.3 \%$. This led to a more friendly germination of weed seeds and made it possible to more effectively clean the soil by destroying their seedlings.

The content of mobile $\mathrm{P}_{2} \mathrm{O}_{5}$ in the upper 0-10 cm layer of the soil increased more significantly with a combination of organic-mineral and mineral fertilizers, as well as with the incorporation of green mass of oilseed radish into the soil on green fertilizer and the abandonment of winter straw in the system of non-waste resource-saving treatment. However, in the deeper layers, it was at a sufficient level with both tillage systems (2.34$2.38 \mathrm{mg} / 100 \mathrm{~g}$ of soil in a layer of 20-30 cm). The decrease in the content of mobile forms of $\mathrm{P} 2 \mathrm{O} 5$ in the soil layers of 10-20, 20-30 cm with prolonged non-fall treatment indicates the need to adjust the system of embedding phosphorus fertilizers while reducing the content of mobile phosphates in deeper layers to a "critical level" (1.5-1.6 mg/100 g of soil).

Multi-depth combined and non-tillage tillage in the field crop rotation with long-term use equally affected the productivity of crops in the field crop rotation in both the first and second rotations. In extreme weather conditions, shallow and surface tillage for winter wheat provided a more harmonious emergence of seedlings and the density of the ear bearing stem and an increase in grain yield by $11.0-16.5 \%$ due to the finely lumpy state of the soil.

The use of mineral and organic fertilizers in crop rotation increased the yield of crop rotation crops by 2.0-2.1 times, respectively, regardless of the method and depth of their embedding in the soil. Crop cultivation of oilseed radish on green fertilizer in combination with the abandonment of winter wheat straw in direct action and aftereffect in the crop rotation showed a positive effect in more humid years.

Differentiated chemical control of weeds in winter wheat, oilseed flax, and sorghum crops by reducing the contamination of agricultural crops contributed to an increase in yield by an average of $19.5 \%$ compared to the herbicide-free background.

Prolonged use in crop rotation, no-till system of conservation tillage (under the first winter wheat disking 8-10 cm BDT-3,0 under the flax cultivation racks PRN-31000 type "Paraplau" 12-14 cm, sorghum silage chisel treatment PCH -2.5 at $25-27 \mathrm{~cm}$, under the following winter wheat cultivation KPE-3.8 by $8-10 \mathrm{~cm}$, spring barley - processing with chisel $\mathrm{PCH}-2.5$ at $14-16 \mathrm{~cm}$ ) allows to reduce the energy and economic costs in comparison with the mid-water combination (KPG-250, PLN-5-35, HDH-7). So, only with small processing for winter wheat, the diesel fuel economy on each hectare was 7 liters.

In the aftereffect of the third rotation of the crop rotation in the link "sainfoin-winter wheat-winter barley", the equivalent influence of the mixed-depth combined and nonfallow resource-saving tillage systems on the yield of cultivated crops on the main indicators of fertility remains.

Thus, the absence of significant changes (deterioration) of the main indicators of fertility of southern chernozem under the influence of long-term (19 years) the resourcesaving non-tillage system of soil tillage in the crop rotation indicates the possibility of longterm minimization of its tillage, including the transition to zero tillage (No-till technology) on southern chernozem with medium and high availability of mobile $\mathrm{P}_{2} \mathrm{O}_{5}$ according to Machigin. In the future, with a decrease in the content of mobile phosphates in the lower 
part of the arable layer $(10-30 \mathrm{~cm})$ to $1.5-1.6 \mathrm{mg} / 100 \mathrm{~g}$. the application of phosphorus and organic fertilizers (manure) should be combined with their plowing in a more stable moisture layer $(15-30 \mathrm{~cm})$.

When switching to direct sowing on soils with an average and lower content of mobile $\mathrm{P}_{2} \mathrm{O}_{5}$, before its implementation, it is advisable to add organic and phosphorus fertilizers to the soil in reserve with a plow for a more uniform distribution of organic matter and providing plants with phosphorus.

At the same time, in the conditions of agricultural production, direct sowing technologies (No-till technologies) have become widespread in recent years.

An important direction for further minimization of tillage in the foothill-steppe and steppe Crimea was the transition to "zero" tillage - No-till technology. It provides for a complete rejection of mechanical tillage through the use of direct sowing seeders-a combined tillage sowing working body that provides the creation of a groove by forming a seedbed for the seeds of cultivated crops coming through a tubular seed line. At the same time, the seeds are supplied with mineral fertilizers through a separate tukoprovod, which are embedded on the side of the seeds deeper by 1-3 cm, depending on the cultivation technology of each crop. Special (depending on the design of the seeder) zagortachami and rollers in a row sown seeds are compacted into the soil under the seed bed, including covered with plant residues of the previous crop.

Demonstrated experimentally and in practice in some farms of the Crimea confirmed that carried out by direct sowing incorporation into the soil of seeds of cultivated crops produces more amicable shoots and formation of the yield of main products, as a rule, not less, and more often higher harvest these crops cultivated on conventional technology (before sowing and after seeding treatment of soil of different guns, separate sowing and rolling grain fields).

In the implementation of No-till technology, the return of nutrients to the soil is achieved by preserving and accumulating on the soil surface plant residues of the cultivated crop, which simultaneously perform a soil protection function and a source of organic matter for the reproduction of soil fertility.

At the same time, the analysis of the results of scientific research and the experience of farms that master this technology in practice (at least 5 years), show that even taking into account the use of mineral fertilizers during sowing, simple, and even more extended reproduction of fertility without including intermediate groundcover crops in this process (technology) is almost impossible.

As long-term field and laboratory studies of Tomashova O. L. and her colleagues show, No-till technology ensures the reproduction of soil fertility only in combination with groundcover intermediate crops of mixed crops, primarily due to the effective use of minimal precipitation during the period from harvesting the main cultivated crop to sowing the subsequent main crop rotation. But the main task performed in this case is the development of the root layer by the emerging variety root system of cultivated groundcover intermediate crops [16].

Based on the analysis of available observations of small-scale field and production experiments performed at the V. I. Vernadsky Crimean Federal University (city Simferopol) and LLC "Sesame-Agro" of the Black Sea region, included in the composition of mixtures of groundcover crops annual sweet clover, oilseed radish, Daikon radish, even in the dry spring-summer-autumn period (May-June, July, August, September, October), forming a powerful central root, including a depth of $5-15 \mathrm{~cm}$, provide additional loosening of the soil, accumulation of biomass in the specified layer of 0.5-5.0 t/ ha, and most importantly - they enrich the underlying root-inhabited part of the soil with an additional mass of organic compounds involved in both organic decomposition and humification processes much more intensively than in natural phytocenoses without human participation 
in this process.

Significantly, although less pronounced, the process of accumulation of organic matter with the root system of groundcover crops occurs when they include winter and spring vetch, phacelia, winter rye, oats, biocomponents of the cabbage family - winter and spring rapeseed, white mustard and Sarepta.

Studies of Tomashova O.L., Perepelitsa A.S. and Perepelitsa S.V. showed that closer to the end of the growing season, most of the cultivated groundcover crops combined the amount of ground and root biomass in 2016-2020 was 10-20 t/ha, and most of the plant components had time to form seeds, which allowed the method of combing to obtain an additional $50-250 \mathrm{~kg} / \mathrm{ha}$ of seeds, which, after completion, provided an additional area of intermediate groundcover crops in the following year. Due to the receipt of additional seeds from such crops, LLC "Sesame-Agro" only in 2020 sowed 550 hectares of groundcover crops from the 1500 hectares under cultivation on the farm.

Harvesting by combing mixtures of groundcover crops with harvesting by combing winter cereals made it possible to ensure the formation of 20-22 centimeters of snow cover in the winter period of the 2019-2020 agricultural year, due to standing stubble, in comparison with 10-12 centimeters of snow on stubble backgrounds of winter cereals with continuous mowing. At the same time, the intake of moisture with snow from the areas cleaned by combing was twice as much as in comparison with the cleaning of serial harvesters of combine harvesters.

\section{Conclusion}

Thus, the inclusion of complex groundcover intermediate crops in the agricultural technology of cultivation in crop rotations will allow:

1. To increase the soil protection stability of agrophytocenoses, especially in the case of heavy rainfall in the summer and autumn periods.

2. Due to the formation of vegetation cover in the fields with the cultivation of agricultural crops using No-till technology, due to the inclusion of ground cover intermediate crops, the possibility of loss of mobile forms of nutrients due to vertical migration during the period of heavy rainfall is eliminated.

3. Due to ground cover crops during the growing season, additional biological "loosening" of the soil by the root systems of plants occurs.

4. Such crops provide photosynthesis of the agrophytocenosis (field) during the growing season and increase the use of headlights throughout the growing season.

5. Due to the accumulation of additional organic mass of plants of groundcover crops, a positive balance of humus is formed and the reproduction of soil fertility is achieved not lower than simple (or even extended).

6. Ultimately, this combination of direct seeding with a wide range of intermediateseeded groundcover crops will allow for more efficient use of soil carbon $\left(\mathrm{CO}_{2}, \mathrm{CH}_{4}\right)$ and replenish its reserves in the soil, and thus reduce greenhouse gas emissions into the atmosphere.

\section{References}

1. Bharat Sharma Acharya, Syam Dodla, L.A. Gaston et al., Soil and Tillage Research 195, 104430 (2019) https://doi.org/10.1016/j.still.2019.104430

2. Yuan Li, Zhou Li, Song Cui et al., Soil and Tillage Research 194, 104292 (2019) https://doi.org/10.1016/j.still.2019.06.009

3. Sh. Torabian, S. Farhangi-Abriz, M.D. Denton, Soil and Tillage Research 185, 113121 (2018) https://doi.org/10.1016/j.still.2018.09.006 
4. Viviana Loaiza Puerta, Engil I. Pujol Pereira, Raphaël Wittwer et al., Soil and Tillage Research 180, 1-9 (2018) https://doi.org/10.1016/j.still.2018.02.007

5. J.H. Zhang, L.Z. Jia, Z.H. Zhang et al., Soil and Tillage Research 183, $42-50$ (2018) https://doi.org/10.1016/j.still.2018.05.015

6. Mark Conyers, Vincevan der Rijt, Albert Oates et al, Soil and Tillage Research 193, 17-26 (2019) https://doi.org/10.1016/j.still.2019.05.021

7. I. Nehmi de Oliveira, Z. Menezesde Souza, L. Henrique Lovera, et al., Agricultural Water Management 225, 105777 (2019) https://doi.org/10.1016/j.agwat.2019.105777

8. M.R. Nunes, D.L. Karlen, K.S. Veum et al., Geoderma 369, 114335 (2020) https://doi.org/10.1016/j.geoderma.2020.114335

9. L. Büchi, M. Wendling, C. Amossé et al., Soil and Tillage Research 174, 120-129 (2017) https://doi.org/10.1016/j.still.2017.07.002

10. P. Sanginés de Cárcer, S. Sinaj, M. Santonja et al., Soil and Tillage Research, 190, 209-219 (2019). https://doi.org/10.1016/j.still.2019.01.012

11. Yuhui Niu, Yanjiang Cai, Zengming Chen et al., Soil and Tillage Research 195, 104419 (2019) https://doi.org/10.1016/j.still.2019.104419

12. L. Büchi, M. Wendling, C. Amossé et al., Agriculture, Ecosystems \& Environment 256, 92-104 (2018) https://doi.org/10.1016/j.agee.2018.01.005

13. T. Tiecher, A. Calegari, L. Caner, et al., Geoderma 308, 78-85 (2017) https://doi.org/10.1016/j.geoderma.2017.08.028

14. Yuan Li, Zhou Li, Scott X. Chang et al., Science of The Total Environment 740, 140147 (2020) https://doi.org/10.1016/j.scitotenv.2020.140147

15. O. Tomashova, N. Osenniy, S. Abdurashytov et al., E3S Web of Conferences 210 (2020) https://doi.org/10.1051/e3sconf/202021004010 